\title{
Rhodamine 123 efflux in human subpopulations of hematopoietic stem cells: Comparison between bone marrow, umbilical cord blood and mobilized peripheral blood $\mathrm{CD34}^{+}$cells
}

\author{
KAREN WAGNER-SOUZA ${ }^{1}$, HILDA RACHEL DIAMOND ${ }^{1}$, MARIA HELENA ORNELLAS ${ }^{1}$, \\ BERNADETE EVANGELHO GOMES ${ }^{1}$, ALINE ALMEIDA-OLIVEIRA ${ }^{1}$, ELIANA ABDELHAY ${ }^{1}$, \\ LUIS FERNANDO BOUZAS ${ }^{1}$ and VIVIAN MARY RUMJANEK ${ }^{2}$
}

\begin{abstract}
${ }^{1}$ Laboratório de Imunologia do Centro Nacional de Transplante de Medula Óssea, Instituto Nacional de Câncer (INCA), Praça da Cruz Vermelha, 23-6 ${ }^{0}$ andar, CEP: 20230-130; ${ }^{2}$ Laboratório de Imunologia Tumoral, Instituto de Bioquímica Médica, Centro de Ciências da Saúde, Universidade Federal do Rio de Janeiro (UFRJ),

Cidade Universitária, CEP: 21941-590, RJ, Brazil
\end{abstract}

Received February 21,2008; Accepted April 24, 2008

DOI: $10.3892 /$ ijmm_00000014

\begin{abstract}
Hematopoietic stem cells (HSC) can be identified by the expression of the CD34 molecule. CD34+ cells are found in bone marrow (BM), umbilical cord blood (UCB) and in mobilized peripheral blood (PB). CD34+ cells express $\mathrm{P}$-glycoprotein (Pgp), a product of the multidrug resistance (MDR) gene. Pgp activity can be measured by the efflux of the dye Rhodamine 123 (Rho 123) and can be blocked by verapamil. Transport activity in HSC suggests that Pgp could have a functional role in stem cell differentiation. This study compared the number of CD $34^{+}$cells with Pgp activity measured by efflux of Rho 123 in the hematopoietic population obtained from different sources. Samples were analysed for their content of $\mathrm{CD}_{3} 4^{+}$cells, and $\mathrm{BM}$ had a significantly higher amount of $\mathrm{CD}_{3} 4^{+}$cells compared to UCB, mobilized PB and normal PB. When the frequency of Rho ${ }^{\text {low }}$ cells was studied among the $\mathrm{CD}_{3} 4^{+}$population, an enrichment of cells with Pgp activity was observed. The frequency in BM was significantly lower than that in UCB and mobilized PB. The low retention of Rho 123 could be modified by verapamil, indicating that the measurements reflected dye efflux due to Pgp activity. Although UCB and mobilized PB had a lower number of $\mathrm{CD} 34^{+}$cells compared to BM, the total number of $\mathrm{CD} 34^{+}$cells with Pgp activity was similar in the three tissues. The different profiles may indicate the existence of subpopulations of stem cells or different stages of cellular differentiation detected by the extrusion of the dye Rho 123.
\end{abstract}

Correspondence to: Dr Karen Wagner-Souza, Laboratório de Imunologia do Centro Nacional de Transplante de Medula Óssea, Instituto Nacional de Câncer (INCA), Praça da Cruz Vermelha, 23-6 ${ }^{0}$ andar, CEP: 20230-130, RJ, Brazil

E-mail: kawasoinca@yahoo.com.br

Key words: Rhodamine 123, P-glycoprotein, CD $34^{+}$cells, bone marrow, umbilical cord blood

\section{Introduction}

Hematopoietic stem cells (HSC) are characterized by their ability to self-renew and differentiate into multipotent progenitors, which develop subsequently into myeloid and lymphoid cells $(1,2)$. The first quantitative in vivo study of stem cells was conducted in 1961 by Till and McCulloch (3), demonstrating that a single precursor cell exists in the bone marrow (BM) of adult animals which is capable of both extensive self-renewal and multi-lineage differentiation. HSC can be characterized based on both phenotype and function. The human CD34 protein is a developmental stage-specific surface antigen expressed in hematopoietic stem and progenitor cells, and it has been used for the selection of long-term repopulating cells $(4,5)$. Therefore, $\mathrm{CD} 4^{+}$cells are commonly used in hematopoietic stem cell transplantation. CD34 ${ }^{+}$cells are found in BM (6), umbilical cord blood (UCB) (7) and in peripheral blood $(\mathrm{PB})$ where they are extremely rare. They can be mobilized to the periphery by means of chemotherapy and/or cytokine treatment, such as G-CSF (granulocyte colonystimulating factor), increasing their numbers in the circulation $(8,9)$. Therefore, UCB and mobilized PB have become important in the study of hematopoiesis, and they are being used as alternative sources to BM for HSC transplantation $(7,10)$. Despite the lack of a universal protocol for the enumeration of $\mathrm{CD}_{3} 4^{+}$cells, there is a general consensus that reliable engraftment can occur in patients receiving at least $2 \times 10^{6} \mathrm{CD} 34^{+}$cells $/ \mathrm{kg}$ body weight for mobilized PB $(11,12)$, $0.8-1.7 \times 10^{5} \mathrm{CD}^{2} 4^{+}$cells $/ \mathrm{kg}$ for UCB $(13,14)$, and $0.5-2 \times 10^{6}$ $\mathrm{CD} 34^{+}$cells $/ \mathrm{kg}$ for BM $(12,15)$. It is not clear, however, if $\mathrm{CD} 34^{+}$cells from all of these sources represent the same type of cell.

Another functional and phenotypical method of enriching HSC exploits the fact that some cells have evolved a cellular protection mechanism against toxic metabolites and xenobiotics. This mechanism involves the expression of efflux pumps that belong to the ATP-binding cassette (ABC) superfamily of membrane transporters (16). The best studied 
transporter, P-glycoprotein (Pgp or ABCB1), is a $170-\mathrm{kDa}$ transmembrane glycoprotein (17) encoded by the multidrug resistance 1 (MDR 1) gene $(18,19)$. Pgp acts as an ATPdependent efflux pump that prevents the accumulation of many natural substances and anticancer drugs. MDR 1 gene expression is frequently observed in different human tumors and correlates with resistance to chemotherapy (20). In addition to neoplastic cells, a variety of normal human tissues (kidney, colon, blood-brain barrier, liver and hematopoietic tissue) are known to express Pgp at different levels (21), and it is thought to play an important role in removing toxic metabolites from cells (22). In the hematopoietic compartment, Pgp is expressed by peripheral blood lymphocytes, especially $\mathrm{CD}^{2} 6^{+}$natural killer and $\mathrm{CD} 8^{+}$cytotoxic $\mathrm{T}$ cells, as well as by CD34+ HSC $(23,24)$. Several lines of evidence suggest that Pgp expression is functionally conserved in HSC (23-25). HSC can be identified based on their ability to efflux fluorescent dyes, such as Rhodamine (Rho) 123 (26). Rho 123 is a known substrate for Pgp and has been used extensively as an indicator for Pgp activity $(27,28)$. This transporter molecule can be modulated by a series of substances known as Pgp reversers. Among these the first studied was the calciumchannel inhibitor, verapamil (VP), which blocks Pgp function (29). Transport activity in HSC suggests the possibility that Pgp could have a functional role in stem cell regulation (30). Indeed, other studies have demonstrated that stem cell populations can differ in their ability to accumulate Rho 123 and that this dye can be used to define functionally distinct subpopulations of primitive stem cells (31-33). It was also reported that the hematopoietic population that expresses CD34 and retains low levels of Rho 123 is responsible for the longterm repopulation $(31,33,34)$. The exact phenotype of HSC is still unknown, and additional approaches to further purify HSC can lead to a better characterization of the behavior of these cells from different sources. The aim of the present study was to compare the amount of CD34+ cells with Pgp activity, measured by efflux of Rho 123, in the hematopoietic population obtained from different sources.

\section{Materials and methods}

Samples. Human hematopoietic cells from BM $(n=14)$, UCB $(\mathrm{n}=11)$, normal $\mathrm{PB}(\mathrm{n}=5)$ and mobilized $\mathrm{PB}(\mathrm{n}=8$, following $10 \mu \mathrm{g} / \mathrm{kg} /$ day of G-CSF-filgrastim treatment for 5 days) of healthy donors were obtained from the Instituto Nacional de Câncer (INCA). This study had the informed consent from the healthy donors, and the protocol was approved by the local ethics committee.

Rhodamine 123 efflux assay and immunophenotyping. The Pglycoprotein activity was determined by means of Rho 123 (Sigma) efflux, as this fluorescent dye is a substrate for Pgp $(27,28)$. Aliquots of cell suspension $\left(1 \times 10^{6}\right.$ cells $\left./ \mathrm{ml}\right)$ were incubated with $200 \mathrm{ng} / \mathrm{ml}$ of Rho 123 dye in the presence or absence of the Pgp inhibitor, verapamil (VP) (Sigma) at a concentration of $10 \mu \mathrm{M}$ for $30 \mathrm{~min}$ at $37^{\circ} \mathrm{C}$ in a humidified atmosphere of air and $5 \% \mathrm{CO}_{2}$. After washing, cells were incubated in a Rho 123 -free medium supplemented with $10 \%$ foetal bovine serum (Gibco), in the presence or absence of VP for $90 \mathrm{~min}$. Finally, cells were washed and incubated with
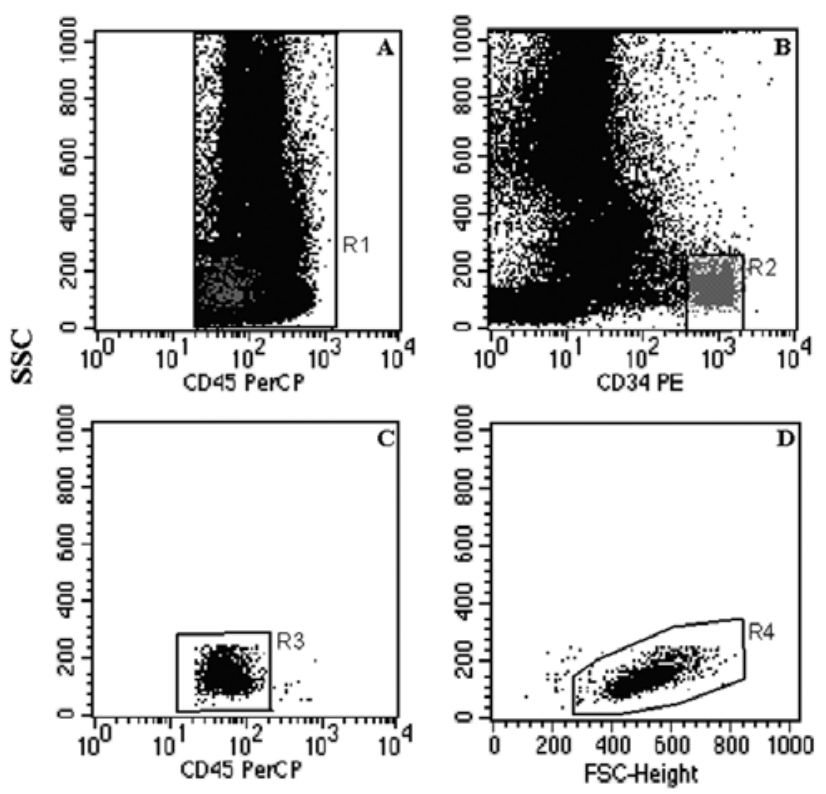

Figure 1. Detection of $\mathrm{CD} 34^{+}$cells. The first stage (A) involved gating $\mathrm{CD} 45^{+}$cells, which was followed (B) by analyzing the $\mathrm{CD} 34^{+}$population among the $\mathrm{CD}_{4} 5^{+}$cells. The third stage (C) involved gating the CD45 low to intermediate population among $\mathrm{CD} 34^{+} / \mathrm{CD} 45^{+}$cells. The last stage (D) refers to the characteristic light scatter properties of the population gated in $\mathrm{C}$.

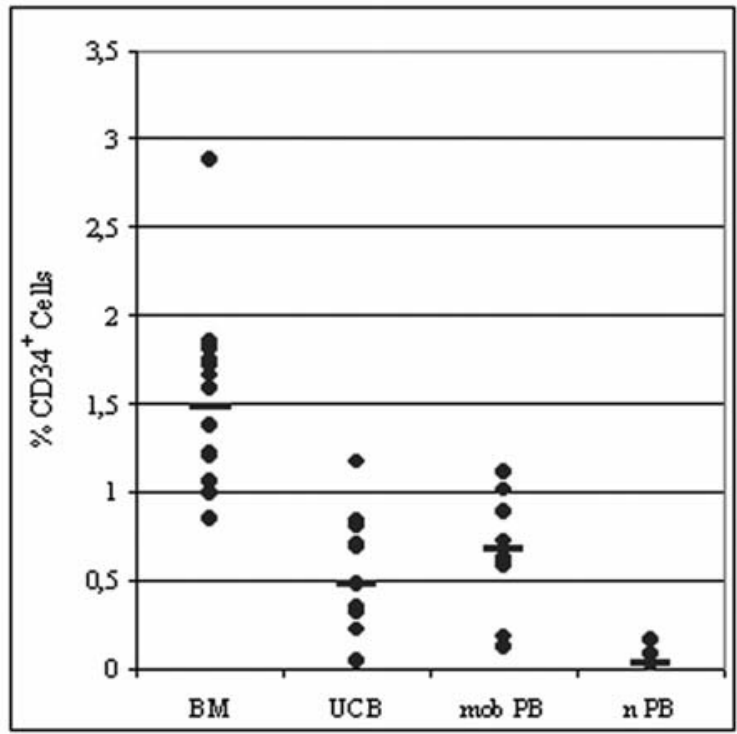

Figure 2. Percentage of $\mathrm{CD} 34^{+}$cells present in different sources of stem cells. BM, bone marrow $(n=14)$; UCB, umbilical cord blood $(n=11)$; mob PB, peripheral blood following treatment with G-CSF $(n=8)$ and $n \mathrm{~PB}$, peripheral blood without mobilization $(n=5)$. The dots represent different individuals, and the horizontal line, the median value.

anti-CD34 phycoerythin (PE)-labeled monoclonal antibody (Becton Dickinson) for 30 min at $4^{\circ} \mathrm{C}$ combined with antiCD45 Peridinin chlorophyll protein (PerCP)-labeled monoclonal antibody (Becton Dickinson) (the pan-leukocyte marker CD45 is differentially expressed in the leukocyte subpopulations). Then, the cells were resuspended in $1 \mathrm{ml}$ of lysing solution (for total lyses of erythrocytes) for $1 \mathrm{~min}$, 
Table I. Comparison of the percentage of $\mathrm{CD}^{3} 4^{+}$cells present in the different sources.

\begin{tabular}{lcccc}
\hline & \multicolumn{4}{c}{ Source } \\
\cline { 2 - 5 } & $\mathrm{BM}$ & $\mathrm{UCB}$ & mob PB & $\mathrm{n} \mathrm{PB}$ \\
\hline $\begin{array}{l}\text { \% CD34 cells/ } \\
\text { total leukocytes }\end{array}$ & 1.48 & 0.48 & 0.67 & 0.03 \\
$\begin{array}{l}\text { \% Rho } \\
\text { CD34 cells/ }\end{array}$ & 26.20 & 71.11 & 61.55 & 56.92 \\
$\begin{array}{l}\text { \% of cells among } \\
\text { leukocytes which are CD34 } \\
\text { and Rholow }\end{array}$ & 0.39 & 0.34 & 0.41 & 0.02 \\
\hline
\end{tabular}

Results are expressed as the median of the frequency (\%) among the cells of different sources. BM, bone marrow $(n=14)$; UCB, umbilical cord blood $(\mathrm{n}=11)$; mob $\mathrm{PB}$, peripheral blood following treatment with G-CSF $(n=8)$ and $n \mathrm{~PB}$, peripheral blood without mobilization $(\mathrm{n}=5)$.

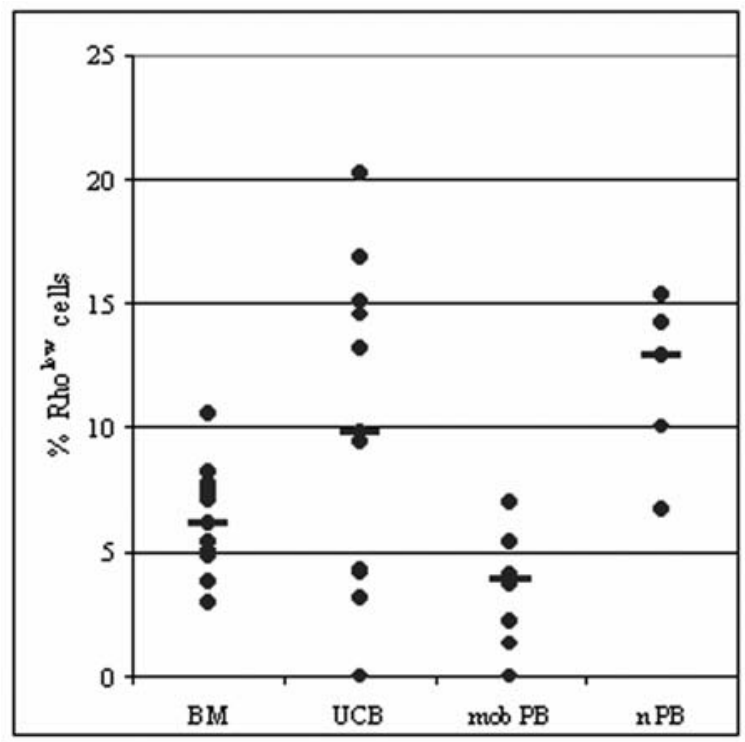

Figure 3. Percentage of cells with Pgp activity (Rho ${ }^{\text {low }}$ ) present in different sources of stem cells. BM, bone marrow $(n=14)$; UCB, umbilical cord blood $(\mathrm{n}=11)$; mob PB, peripheral blood following treatment with G-CSF $(n=8)$ and $\mathrm{n}$ PB, peripheral blood without mobilization $(n=5)$. The dots represent different individuals, and the horizontal line, the median value.

washed and resuspended in phosphate-buffered saline containing $0.1 \%$ sodium azide and $0.5 \%$ bovine serum albumin. Cells were used for the analysis of antigen expression and for studies of Pgp activity.

Flow cytometric study. Data acquisition and analysis were performed using a FACScalibur (Becton Dickinson) equipped with a 488-nm argon laser. To investigate dye efflux in $\mathrm{CD}^{2} 4^{+} / \mathrm{CD} 45^{+}$cells, this cell subset was further identified using multiple gating methods, according to the ISHAGE protocol for enumeration of $\mathrm{CD} 34^{+} \mathrm{HSC}(35) . \mathrm{CD}^{+} 4^{+}$cells

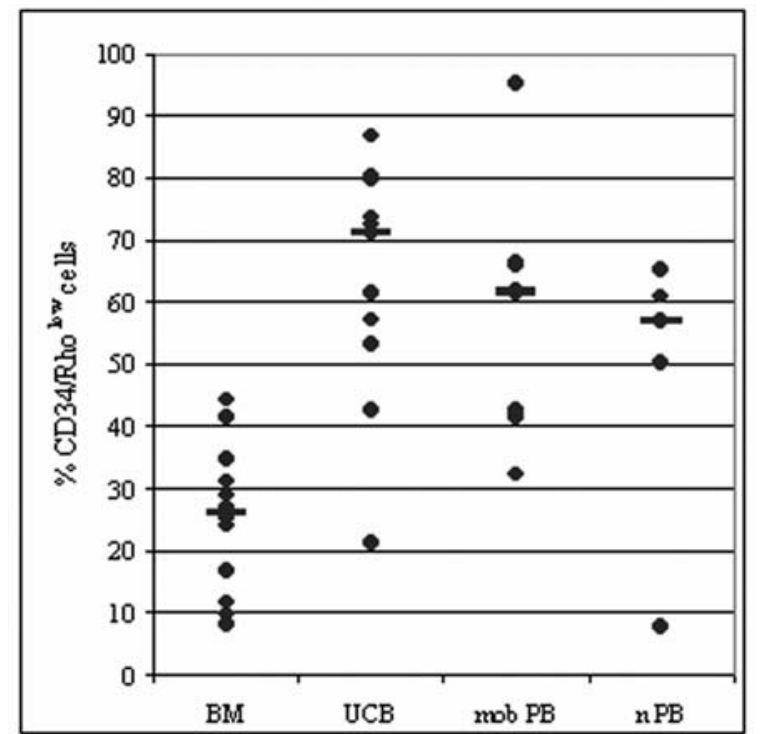

Figure 4 . Percentage of $\mathrm{CD} 34^{+} / \mathrm{Rho}^{\text {low }}$ cells present in different sources of stem cells. BM, bone marrow $(n=14)$; UCB, umbilical cord blood $(n=11)$; mob PB, peripheral blood following treatment with G-CSF $(n=8)$ and $n$ PB, peripheral blood without mobilization $(n=5)$. The dots represent different individuals, and the horizontal line, the median value.

are rare events. A gating strategy that uses light scattering parameters and CD34/CD45 fluorescence aids ensures accurate identification and enumeration. From the gated CD34/ CD45 population, the CD34+ cells were identified in a CD34 vs SSC dot plot (Fig. 1). Rho 123 efflux was calculated based on the percentage of dye-effluxing cells in the VP-free experiment, compared with cells treated with VP.

Statistical analysis. The Mann-Whitney non-parametric test was performed to assess the statistical differences between groups, where p-values $\leq 0.05$ were considered statistically significant.

\section{Results}

Samples from different sources were analysed for their content of $\mathrm{CD} 34^{+}$cells. The median values of $\mathrm{CD} 34^{+}$cells were $1.48 \%$ for BM, $0.48 \%$ for UCB, $0.67 \%$ for mobilized PB and $0.03 \%$ for normal PB (Fig. 2, Table I). BM had significantly higher numbers of $\mathrm{CD} 4^{+}$cells compared to $\mathrm{UCB}(\mathrm{p}=0.0001)$, mobilized PB $(p=0.0002)$ and normal PB $(p=0.0001)$. There was no difference between UCB and mobilized PB $(p=0.27)$, but normal $\mathrm{PB}$ had less $\mathrm{CD} 34^{+}$cells compared to $\mathrm{UCB}$ $(\mathrm{p}=0.0009)$ and mobilized PB $(\mathrm{p}=0.0016)$.

The next step involved establishing the frequency of cells showing Pgp transport activity, i.e., accumulation of low amounts of the dye (Rholow). The median values obtained were $6.14 \%$ among BM cells, $9.83 \%$ in UCB, $3.91 \%$ in mobilized PB and $12.87 \%$ in normal PB (Fig. 3). Statistical analysis indicated that there was no difference between BM and UCB $(\mathrm{p}=0.14)$, however, $\mathrm{BM}$ had significantly more cells compared to mobilized $\mathrm{PB}(\mathrm{p}=0.02)$ and less cells compared to normal PB $(p=0.007)$. When the proportion of UCB cells was compared, there was a significant difference between this 


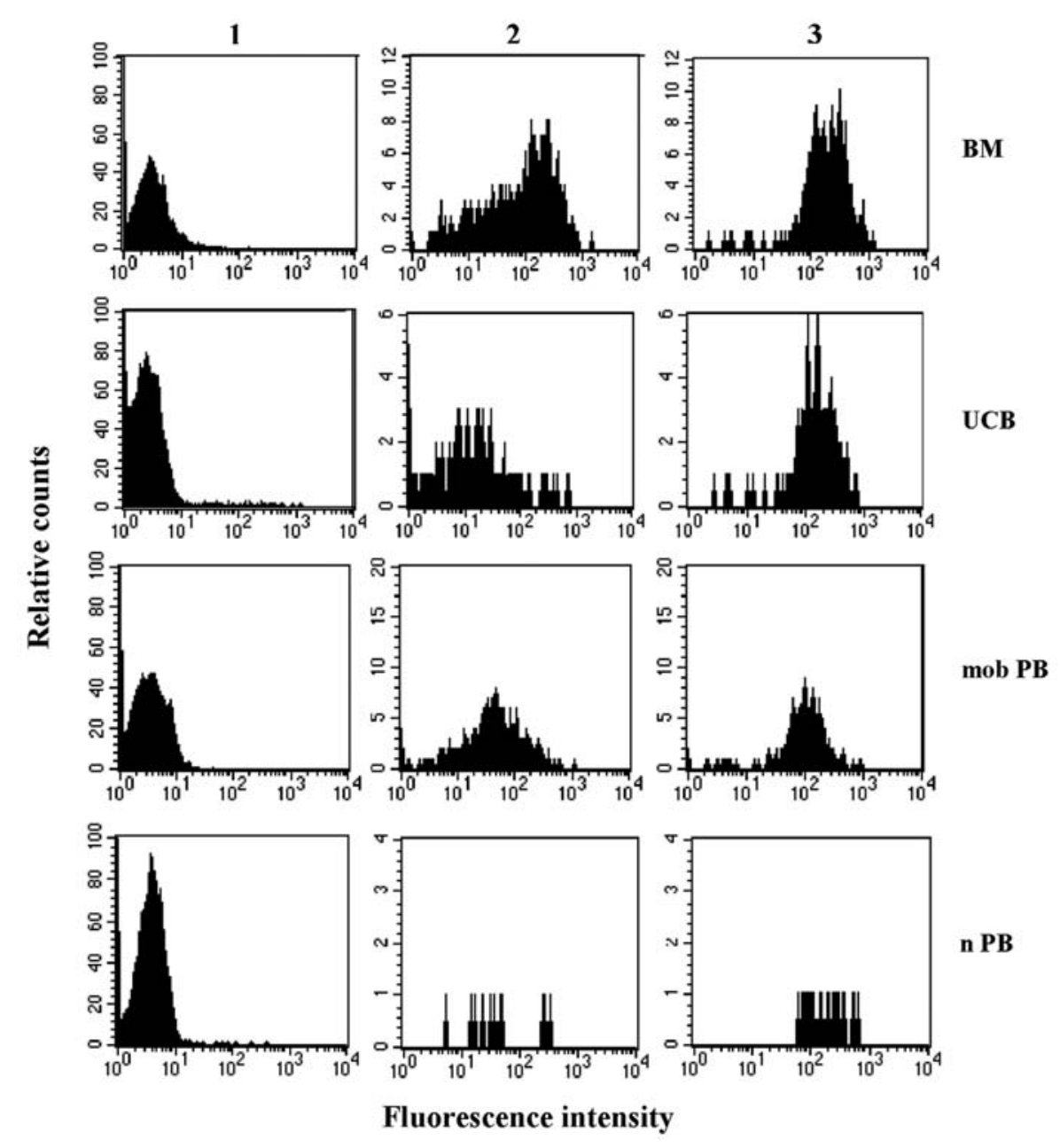

Figure 5. Rho 123 accumulation in $\mathrm{CD} 34^{+}$cells from different sources of stem cells. BM, bone marrow; UCB, umbilical cord blood; mob PB, peripheral blood following treatment with G-CSF and n PB, peripheral blood without mobilization. (1) Auto-fluorescence of cells without Rho 123; (2) cells incubated with $200 \mathrm{ng} / \mathrm{ml}$ of Rho 123 and left to extrude the dye and (3) cells incubated with $200 \mathrm{ng} / \mathrm{ml}$ of Rho 123 and the Pgp inhibitor verapamil (10 $\mu$ M). This result is a representative experiment of all the samples tested.

population and mobilized PB ( $\mathrm{p}=0.03$ ) but not between UCB and normal $\mathrm{PB}(\mathrm{p}=0.66)$. Mobilized $\mathrm{PB}$ had a significantly lower number of Rholow cells compared to normal PB $(\mathrm{p}=0.003)$.

Mature cells such as CD8 lymphocytes and NK cells have high Pgp activities, therefore it was important to establish the amount of Rho ${ }^{\text {low }}$ cells among the immature population. When the frequency of Rho ${ }^{\text {low }}$ cells was studied among the CD34+ population (Fig. 4, Table I) it was possible to observe a clear enrichment of cells with Pgp activity; in this case, $26.20 \%$ in the BM, $71.11 \%$ in UCB, $61.55 \%$ in mobilized PB and $56.92 \%$ in normal $\mathrm{PB}$. The frequency in the BM was significantly lower than that in the UCB $(\mathrm{p}=0.0001)$ and mobilized PB $(p=0.0002)$. When UCB was compared against mobilized PB $(\mathrm{p}=0.44)$ and normal $\mathrm{PB}(\mathrm{p}=0.14)$ no significant difference was observed.

Our results of Rho 123 accumulation and efflux, used to determine Rho ${ }^{\text {low }}$ cells, were based on the amount of extrusion that could be blocked by the Pgp inhibitor verapamil (Fig. 5) indicating that differences in the intensity of Rho 123 fluorescence were genuinely due to Pgp activity.

Our data suggest that not all CD34+ cells have Pgp activity. Furthermore, although UCB and mobilized PB had a lower number of $\mathrm{CD} 34^{+}$cells compared to BM, the total amount of CD34+ cells with Pgp activity was similar in the three tissues (Table I). The different profiles may indicate the existence of subpopulations of stem cells or different stages of cellular differentiation detected by the extrusion of the dye Rho 123.

\section{Discussion}

The study of hematopoietic stem cells is limited by the lack of specific markers for HSC. Stem cell populations can be highly enriched by a variety of methods that involve cell surface marker expression or functional characteristics. One of these methods involves the use of the fluorescent dye Rho 123 (26), known as a Pgp substrate. In the current study we investigated whether Rho 123 staining in combination with CD34 could be useful in the identification of distinct populations of HSC of the BM, UCB and mobilized PB.

The leukocytes obtained from different sources were analysed with regard to CD34 expression, and the proportion of $\mathrm{CD}_{3} 4^{+}$cells obtained from the different sources (BM, UCB, mobilized and normal $\mathrm{PB}$ ) were in accordance with that described by other authors $(8,35-37)$. 
When the frequency of Rho ${ }^{\text {low }}$ cells was studied among the $\mathrm{CD} 34^{+}$population of the BM, mobilized and normal $\mathrm{PB}$, our results were consistent with other studies $(23,31,38,39)$. It has been reported $(38,39)$ that $\mathrm{CD}^{2} 4^{+}$cells from mobilized PB retain less Rho 123 than those from the BM. A similar trend was observed by us, with a clear difference between the groups. Furthermore, we observed a significant difference between UCB and BM CD34+ cells. However, UCB CD34+ cells displayed an increased capacity of Rho 123 extrusion, much higher than that reported by other groups $(32,40)$. This discrepancy may be a reflection of the time left for Rho 123 extrusion. Zijlmans et al (26) described that increasing the time of extrusion leads to an augmentation of the proportion of Rholow cells. On the other hand, Hao et al (41) and Mayani et al (42) reported an increased proliferative capacity in CD34+ UCB cells compared to BM. Their results and ours strongly indicate that there are significant functional differences between these two populations. Using different assays, various studies have reported the increased engrafting capacity of UCB cells (43-45).

A number of studies have demonstrated that the hematopoietic population that expresses CD34 and retains low levels of Rho 123 is responsible for long-term repopulation $(31,33,34)$. Low levels of Rho 123 retention could not only reflect extrusion of the dye through Pgp activity $(27,28)$, but also a quiescent state of the cells. The dye Rho 123 accumulates in the mitochondria (46) and, therefore, its retention is also a reflection of mitochondria number and activity, explaining why resting cells accumulate less dye. In the present study, the low retention of Rho 123 was able to be modified by the Pgp inhibitor, verapamil, indicating that what was being measured was dye efflux and not mitochondria function.

These results indicate that Rho 123 staining can be used in combination with CD34 antigen to obtain subpopulations of hematopoietic progenitors. Thus, a combination of Rhodamine efflux and phenotypic selection provides an efficient way to enrich immature cells, and these enriched subpopulations should allow us to further characterize the biology and clinical relevance of HSC.

\section{Acknowledgements}

We are grateful to Dr Pedro Carvalho and Raphael C. Valente for their help with the statistical analysis. This work was supported by Fundação Ary Frauzino (FAF), Brazilian National Research Council (CNPq) and Programa de Núcleos de Excelência (PRONEX). Karen Wagner-Souza received a fellowship from The Brazilian National Research Council (CNPq).

\section{References}

1. Abramson S, Miller RG and Philips RA: The identification in adult bone marrow of pluripotent and restricted stem cells of the myeloid and lymphoid systems. J Exp Med 145: 1567-1579, 1977.

2. Szilvassy SJ: The biology of hematopoietic stem cells. Arch Med Res 34: 446-460, 2003

3. Till $\mathrm{J}$ and McCulloch E: A direct measurement of the radiation sensitivity of normal mouse bone marrow cells. Radiat Res 14: 213-222, 1961.
4. Civin CI, Straus LC, Brovall C, Fackler MJ, Schwartz JF and Shaper JH: A hematopoietic progenitor cell surface antigen defined by a monoclonal antibody raised against KG-1a cells. J Immunol 133: 157-165, 1984.

5. Krause DS, Fackler MJ, Civin CI and May WS: CD34: structure, biology, and clinical utility. Blood 87: 1-13, 1996.

6. Krause DS, Theise ND, Collector MI, et al: Multi-organ, multilineage engraftment by a single bone marrow-derived stem cell. Cell 105: 369-377, 2001

7. Cairo MS and Wagner JE: Placental and/or umbilical cord blood: an alternative source of hematopoietic stem cells for transplantation. Blood 90: 4665-4678, 1997.

8. Siena S, Bregni M, Brando B, Ravagnani F, Bonadonna $G$ and Gianni AM: Circulation of $\mathrm{CD} 34^{+}$hematopoietic stem cells in the peripheral blood of high-dose cyclophosphamide-treated patients: enhancement by intravenous recombinant human granulocyte-macrophage colony-stimulating factor. Blood 74: 1905-1914, 1989.

9. Jansen J, Hanks S, Thompson JM, Dugan MJ and Akard LP: Transplantation of hematopoietic stem cells from the peripheral blood. J Cell Mol Med 9: 37-50, 2005.

10. Arslan Ö and Moog R: Mobilization of peripheral blood stem cells. Transfus Apher Sci 37: 179-185, 2007.

11. Weaver CH, Hazelton B, Birch R, Palmer P, Allen C, Schwartzberg L and West W: An analysis of engraftment kinetics as a function of the CD34 content of peripheral blood progenitor cell collections in 692 patients after the administration of myeloablative chemotherapy. Blood 86: 3961-3969, 1995.

12. Singhal S, Powles R, Treleaven J, et al: A low CD $34^{+}$cell dose results in higher mortality and poorer survival after blood or marrow stem cell transplantation from HLA-identical siblings: should $2 \times 10\left(^{6}\right) \mathrm{CD} 34^{+}$cells $/ \mathrm{kg}$ be considered the minimum threshold? Bone Marrow Transplant 26: 489-496, 2000.

13. Gluckman E, Rocha V and Chevret S: Results of unrelated umbilical cord blood hematopoietic stem cell transplant. Transfus Clin Biol 8: 146-154, 2001.

14. Chao NJ, Emerson SG and Weinberg KI: Stem cell transplantation (cord blood transplants). Hematology 1: 354-371, 2004.

15. Gorin NC, Lopez M, Laporte JP, et al: Preparation and successful engraftment of purified CD $34^{+}$bone marrow progenitor cells in patients with non-Hodgkin's lymphoma. Blood 85: 1647-1654, 1995.

16. Higgins CF: ABC transporters: from microorganisms to man. Annu Rev Cell Biol 8: 67-113, 1992.

17. Juliano RL and Ling V: A surface glycoprotein modulation drug permeability in Chinese hamster ovary cell mutants. Biochim Biophys Acta 455: 152-162, 1976.

18. Ueda K, Cornwell MM, Gottesman MM, Pastan I, Roninson IB, Ling V and Riordan JR: The mdr 1 gene, responsible for multidrug-resistance, codes for P-glycoprotein. Biochem Biophys Res Commun 141: 956-962, 1986.

19. Gottesman MM and Ling V: The molecular basis of multidrug resistance in cancer: the early years of P-glycoprotein research. FEBS Lett 580: 998-1009, 2006.

20. Goldstein LJ, Galski H, Fojo A, et al: Expression of a multidrug resistance gene in human cancers. J Natl Cancer Inst 81: 116-124, 1989.

21. Thiebaut F, Tsuruo T, Hamada H, Gottesman MM, Pastan I and Willingham MC: Cellular localization of the multidrugresistance gene product, P-glycoprotein, in normal human tissues. Proc Natl Acad Sci USA 84: 7735-7738, 1987.

22. Balayssac D, Authier N, Cayre A and Coudore F: Does inhibition of P-glycoprotein lead to drug-drug interactions. Toxicol Lett 156: 319-329, 2005

23. Drach D, Zhao S, Drach J, Mahadevia R, Gattringer C, Huber H and Andreeff M: Subpopulations of normal peripheral blood and bone marrow express a functional multidrug resistant phenotype. Blood 80: 2729-2734, 1992.

24. Chaudhary PM and Roninson IB: Expression and activity of Pglycoprotein, a multidrug efflux pump in human hematopoietic stem cells. Cell 66: 85-94, 1991.

25. Smeets M, Raymakers R, Vierwinden G, et al: A low but functionally significant MDR1 expression protects primitive haematopoietic progenitor cells from anthracycline toxicity. $\mathrm{Br}$ J Haematol 96: 346-355, 1997.

26. Zijlmans JM, Visser JW, Kleiverda K, Kluin PM, Willemze R and Fibbe WE: Modification of rhodamine staining allows identification of hematopoietic stem cells with preferential shortterm or long-term bone marrow-repopulating ability. Proc Natl Acad Sci USA 92: 8901-8905, 1995. 
27. Neyfakh AA: Use of fluorescent dyes as molecular probes for the studies of multidrug resistance. Exp Cell Res 174: 168-176, 1988.

28. Pétriz J and Garcia-López J: Flow cytometric analysis of Pglycoprotein function using rhodamine 123. Leukemia 11: 1124-1130, 1997.

29. Tsuruo T, Iida H, Tsukagoshi S and Sakurai Y: Overcoming of vincristine resistance in P388 leukaemia in vivo and in vitro through enhanced cytotoxicity of vincristine and vinblastine by verapamil. Cancer Res 41: 1967-1972, 1981.

30. Bunting KD: ABC transporter as phenotypic markers and functional regulators of stem cells. Stem Cells 20: 11-20, 2002.

31. Udomsakdi C, Eaves CJ, Sutherland HJ and Lansdorp PM: Separation of functionally distinct subpopulations of primitive human hematopoietic cells using rhodamine-123. Exp Hematol 19: 338-342, 1991

32. Cicuttini FM, Welch KL and Boyd AW: The effect of cytokines on $\mathrm{CD} 34^{+} \mathrm{Rh}-123^{\text {high }}$ and low progenitor cells from human umbilical cord blood. Exp Hematol 22: 1244-1251, 1994.

33. Uchida N, Combs J, Chen S, Zanjani E, Hoffman R and Tsukamoto A: Primitive human hematopoietic cells displaying differential efflux of the rhodamine 123 dye have distinct biological activities. Blood 88: 1297-1305, 1996.

34. McKenzie JL, Takenaka K, Gan OI, Doedens M and Dick JE: Low rhodamine 123 retention identifies long-term human hematopoietic stem cells within the in $^{-} \mathrm{CD} 34^{+} \mathrm{CD} 38^{-}$population. Blood 109: 543-545, 2007.

35. Sutherland DR, Anderson L, Keeney M, Nayar R and Chin-Yee I: The ISHAGE guidelines for $\mathrm{CD} 34^{+}$cells determination by flow cytometry. International Society of Hematotherapy and Graft Engineering. J Hematother 5: 213-226, 1996.

36. Abboud M, Xu F, Lavia M and Laver J: Study of early haematopoietic precursors in human cord blood. Exp Hematol 20: 1043-1047, 1992.

37. D'arena G, Cascavilla N, Musto P, et al: Flow cytometric characterization of $\mathrm{CD} 34^{+}$hematopoietic progenitor cells in mobilized peripheral blood and bone marrow of cancer patients. Haematologica 81: 216-223, 1996.
38. To LB, Haylock DN, Dowse T, Simmons PJ, Trimboli S, Ashman LK and Juttner CA: A comparative study of the phenotype and proliferative capacity of peripheral blood (PB) CD34 ${ }^{+}$ cells mobilized by four different protocols and those of steadyphase PB and bone marrow CD34+ cells. Blood 84: 2930-2939, 1994.

39. Croockewit AJ, Raymakers RA, Smeets ME, vd Bosch G, Pennings AH and De Witte TJ: The low cycling status of mobilized peripheral blood $\mathrm{CD} 34^{+}$cells is not restricted to the more primitive subfraction. Leukemia 12: 571-577, 1998.

40. Liu H and Verfaillie CM: Myeloid-lymphoid initiating cells (ML-IC) are highly enriched in the rhodamine-c-kit( $\left(^{+}\right) \mathrm{CD} 33\left(^{-}\right)$ CD38( $\left(^{-}\right)$fraction of umbilical cord CD34 $\left(^{+}\right)$cells. Exp Hematol 30: 582-589, 2002.

41. Hao QL, Shah AJ, Thiemann FT, Smogorzewska EM and Crooks GM: A functional comparison of CD $34^{+} \mathrm{CD} 38^{-}$cells in cord blood and bone marrow. Blood 86: 3745-3753, 1995.

42. Mayani H, Alvarado-Moreno JÁ and Flores-Guzmán P: Biology of human hematopoietic stem and progenitor cells present in circulation. Arch Med Res 34: 476-488, 2003.

43. Pettengell R, Luft T, Henschler R, Hows JM, Dexter TM, Ryder D and Testa NG: Direct comparison by limiting dilution analysis of long-term culture-initiating cells in human bone marrow, umbilical cord blood, and blood stem cells. Blood 84: 3653-3659, 1994

44. Wang JC, Doedens M and Dick JE: Primitive human hematopoietic cells are enriched in cord blood compared with adult bone marrow or mobilized peripheral blood as measured by the quantitative in vivo SCID-repopulating cell assay. Blood 89: 3919-3924, 1997.

45. Lewis ID, Almeida-Porada G, Du J, Lemischka IR, Moore KA, Zanjani ED and Verfaillie CM: Umbilical cord blood cells capable of engrafting in primary, secondary, and tertiary xenogeneic hosts are preserved after ex vivo culture in a noncontact system. Blood 97: 3441-3449, 2001.

46. Johnson LV, Walsh ML and Chen LB: Localization of mitochondria in living cells with rhodamine 123. Proc Natl Acad Sci USA 77: 990-994, 1980. 